\title{
COPENHAGEN NATURAL RADIOCARBON MEASUREMENTS III, CORRECTIONS TO RADIOCARBON DATES MADE WITH THE SOLID CARBON TECHNIQUE
}

\author{
HENRIK TAUBER \\ Carbon-14, Dating Laboratory \\ Department of Natural Sciences, National Museum, Copenhagen \\ INTRODUCTION: THE SUESS EFFECT IN DENMARK
}

In the Copenhagen $\mathrm{I}$ and II date lists radiocarbon dates for samples representing the late-glacial Allerød oscillation and early Neolithic periods in Switzerland and Denmark were given. At the time of publication no account was taken of the dilution of the atmosphere with inactive carbon by the extensive combustion of fossil fuels since the Industrial Revolution (Suess, 1955), and of its influence on the dating results. This effect as measured by Suess amounted to $3.4 \%$ depletion in wood samples from the heavily industrialized east coast of the United States. Several later measurements have shown that the magnitude of this reduction in atmospheric $\mathrm{C}^{14}$ concentration varies in different areas. The average universal decrease was calculated by Fergusson (1958) as $2.03 \pm .15 \%$. However, the magnitude of reported Suess effects may vary with the chosen reference sample as a result of periodic changes (de Vries effect) in the atmospheric $\mathrm{C}^{14}$ concentration as found by de Vries (1958).

The samples used as contemporary standards in calculating the dates in the above-mentioned lists were wood of beech, pine, and birch, which were growing near Copenhagen during 1951-1953. The measurements were performed with the solid-carbon method.

In order to check the magnitude of the Suess effect in the Copenhagen area and to determine the proper corrections to be applied to the previous measurements, the black-carbon materials of the former standards were combusted and measured with the $\mathrm{CO}_{2}$ method. After normalization to a common $\mathrm{C}^{13} / \mathrm{C}^{12}$ ratio these measurements showed an average depression of $2.5 \pm$ $0.5 \%$ in $\mathrm{C}^{14}$ activity compared to $95 \%$ of the measured activity of the NBS oxalic-acid standard. The value $95 \%$ of the activity of the NBS oxalic-acid standard was chosen at the Groningen $\mathrm{C}^{14}$ conference in 1959 as a general standard for the calculation of $\mathrm{C}^{14}$ dates; the value corresponds closely to the average age-corrected activity of 19 th century wood and also to the average activity of living plant material for the last 1300 years (Willis, Tauber, and Münnich, 1960).

\section{ACKNOWLEDGMENT}

The $\mathrm{C}^{13} / \mathrm{C}^{12}$ ratios of the standards were kindly measured by $\mathrm{W}$. Dansgaard, Biophysical Laboratory, University of Copenhagen. 
I. AGE CORRECTIONS TO COPENHAGEN I AND II

The reduction of $2.5 \pm 0.5 \%$ in the $\mathrm{C}^{14}$ concentration of the former standards has made all dates in the two date lists $200 \pm 40$ years too young. Hence, this number of years (200) should be added to all dates in the two publications. After this correction the dates may be considered as based on a contemporary value of $95 \%$ of the activity of the oxalic-acid standard. Dates from the Copenhagen Laboratory published later than Copenhagen I and II have been corrected for Suess effect by the use of 19th century wood as a reference standard, except for the dates mentioned and corrected in section II of this paper.

The main results of this correction are the changes in the dates for the pollen-zone boundary II/III, the pollen-zone boundary III/IV, and for the average ages of the Neolithic dwelling places Egolzwil-3 in Switzerland and Mul. I in Denmark. The corrected dates are given below in years before 1950; the corrected dates in the B.C.-A.D. scale, which are the official dates from the laboratory, are added in parentheses in the sample description.

Ruds Vedby series, Denmark, recalculated

Exposed Allerød section at Ruds Vedby (55 $32^{\prime}$ N Lat, $11^{\circ} 22^{\prime}$ E Long), Zealand, Denmark. Here the Allerød stratigraphy presents itself in the classical form as thin, distinct layers of organic lake mud interposed between two thick layers of clay (Iversen, 1953; Krog, 1954).

K-101 bis. Wood, zone boundary II/III

$11,090 \pm 210$

Wood from a thin, dark layer representing the exact pollen-zone boundary II/III, Allerød-Younger Dryas. The wood was isolated from the peaty lake mud. (Age $9140 \pm 240$ B.C.). Comment: K-101 has been used extensively as a cross-checking sample: Suess (1954), Münnich (1957), de Vries, Barendsen, and Waterbolk (1958), Barker and Mackey (1959), Olsson (1959). Most of these dates are corrected for Suess effect, but not all. The dates are calculated on the basis of local standards which may expose minor deviations.

K-101 bis, 102 bis, and 103 bis. Average: 11,030 \pm 200

Average for pollen-zone boundary II/III, Allerød-Younger Dryas, at Ruds Vedby. (Age $9080 \pm 200$ B.c.)

Bølling series, Denmark, recalculated

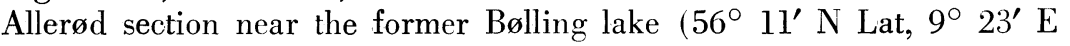
Long), Jutland, Denmark. The site is located in a very poor outwash plain in Jutland. All samples are noncalcareous (Iversen, 1953).

K-110 bis. Lake mud, zone boundary II/III $10,970 \pm 300$

A thin layer, 1 to $1.5 \mathrm{~cm}$, of noncalcareous lake mud representing the pollen-zone boundary II/III, Allerød-Younger Dryas. (Age $9020 \pm 300$ B.c.)

K-111 bis. Lake mud, zone boundary III/IV $10,500 \pm 350$

Noncalcereous lake mud from the pollen-zone boundary III-IV, Younger Dryas-Pre-Boreal. (Age $8550 \pm 350$ B.c.)

Egolzwil-3 series, Switzerland, recalculated

Samples from the Neolithic dwelling place Egolzwil-3 $\left(47^{\circ} 11^{\prime} \mathrm{N}\right.$ Lat, 
$5^{\circ} 41^{\prime}$ E Long), Wauwilermoos, Lucerne, Switzerland. The dwelling place belongs to the Older Cortaillod Culture (Vogt, 1951; Troels-Smith, 1956) and represents the oldest agriculture so far found in central Switzerland. Pollen-analytically dated to the time immediately after the first strong decline of the beech curve. Samples K-115, 116, 118, 121, which consisted of wood, bark, and charcoal, were taken from a culture layer only a few in. thick, completely embedded in sterile lake marl. The dates were also published in Levi and Tauber (1955).

$$
\text { Average for the culture layer }(2940 \pm 90 \text { B.c. }) \quad 4890 \pm 90
$$

\section{Mul. I series, Denmark, recalculated}

Samples from the Neolithic dwelling place Mul. I $\left(55^{\circ} 35^{\prime} \mathrm{N}\right.$ Lat, $11^{\circ}$ $30^{\prime}$ E Long) in the bog Aamosen, West Zealand, Denmark. Represents the earliest (phase A, pre-dolmen) Neolithic period in Denmark (Troels-Smith, 1953, 1956). The culture remains, which are of late Ertebølle culture, were deposited in a thin layer on a floating island of swamp peat. Samples K-123, $124,125,126,127,128,129,131,132$, consisted of swamp peat, alderwood peat, bark, hazelnut shells, and charcoal.

$$
\text { Average for the culture layer }(2820 \pm 80 \text { B.c. }) \quad 4770 \pm 80
$$

\section{CORRECTIONS TO SOLID-CARBON DATES NOT INCLUDED IN COPENHAGEN I AND II}

The following measurements were made up to June 1955. They have not been included in date lists, but most of the dates have been discussed in archaeologic or geologic publications. The technique used was described in Copenhagen I. The results given here are corrected by adding 200 years. Only dates from periods with no radioactive contamination of the atmosphere by fallout products are included.

\section{A. Alaska}

K-108. Trail Creek, cave 9, charcoal

$1260 \pm 130$

Charcoal from fireplace in cave $9\left(65^{\circ} 48^{\prime} \mathrm{N}\right.$ Lat, $163^{\circ} 13^{\prime} \mathrm{W}$ Long $)$, Trail Creek, Alaska, U.S.A. The limestone cave, $30 \mathrm{mi}$ inland from Deering, had two narrow passages, one $\mathrm{N} / \mathrm{S}$ and another $\mathrm{E} / \mathrm{W}$. At the crossing point of the passages, $30 \mathrm{~cm}$ below the surface, the fireplace was discovered. The cave served as shelter for caribou hunters; implements of several stages of culture (Larsen, 1950, 1953) were found in it. Coll. 1950 and subm. by Helge Larsen, National Museum, Copenhagen. (Age $690 \pm 130$ A.D.)

\section{K-147. Trail Creek, cave 9, antler}

Antler of caribou from cave $9\left(65^{\circ} 48^{\prime} \mathrm{N}\right.$ Lat, $163^{\circ} 13^{\prime} \mathrm{W}$ Long $)$, Trail Creek, Alaska, U.S.A. (see K-108). The antler was found in the S passage, $6 \mathrm{~m}$ from the entrance, and $70 \mathrm{~cm}$ below the present surface (Larsen 1951, 1953). Coll. 1950 and subm. by Helge Larsen, National Museum, Copenhagen. (Age $670 \pm 120$ B.c.) Comment: antler is liable to infiltrations by foreign material. The surface layers of the antler were removed before dating. 
K-109. Platinum Village site

Average: $1500 \pm 120$

Charcoal from wall timber from burnt house at Platinum Village site $\left(59^{\circ} 01^{\prime} \mathrm{N}\right.$ Lat, $161^{\circ} 50^{\prime} \mathrm{W}$ Long), Alaska. U.S.A. The house contained Paleo-Eskimo implements of types related to Ipiutaq and Near Ipiutaq Culture (Larsen, 1950). (Average age $450 \pm 120$ A.D.) Coll. 1948 and subm. by Helge Larsen, National Museum, Copenhagen. Date is the average of two measurements :

K-109A.

$1550 \pm 150$

K-109B.

$1440 \pm 170$

\section{B. Greenland}

\section{Igdlorssuit series}

Samples from Igdlorssuit $\left(69^{\circ} 59^{\prime} \mathrm{N}\right.$ Lat, $51^{\circ} 21^{\prime}$ W Long), Jacobshavn district, West Greenland. On a gravel plain $2 \mathrm{~m}$ above sealevel between the three excavated house ruins XII, XIII, and XVIII, an area of about $20 \mathrm{sq} \mathrm{m}$ was cleared, revealing a culture layer containing stone implements and refuse, a number of flat stones, and a fireplace with ashes of burnt heather. Ashes were found over an area of about 2 by $1.8 \mathrm{~m}$ in the middle of the excavated area, but the actual fireplace with a thick layer of black ashes covered about 1.5 by $1 \mathrm{~m}$. The stone implements were of Sarqaq and Dorset types (Larsen and Meldgaard, 1958). Compare also dates for Sarqaq and Dorset Cultures given in Copenhagen IV. Coll. 1953 and subm. by Helge Larsen, National Museum, Copenhagen.

\section{K-144. Igdlorssuit, site I}

$3570- \pm 150$

Ashes with charcoal from the fireplace. (Age $1620 \pm 150$ в.с.).

K-146. Igdlorssuit, site I

$3340 \pm 140$

Ashes with charcoal from same fireplace as K-144. (Age $1390 \pm 140$

B.c.) Comment: the dated samples may contain charcoal from driftwood.

\section{K-145. Igdlorssuit}

$1120 \pm 120$

Ashes with charcoal from fireplace about $100 \mathrm{~m} \mathrm{~N}$ of the group of ruins XII, XIII, and XVIII. Here another find of stone implements of Sarqaq and Dorset Cultures was made in an accumulation of stones close to the shore and just above the high-water mark. In addition to some large stones, which might be part of a stone ring, there were some flat stones and at least two fireplaces with hand-sized, fire-cracked stones. (Age A.D. $830 \pm 120$.) Comment: the dated sample may contain charcoal from driftwood.

K-138. Prinsesse Ingeborg Halv $\varnothing \quad 4040 \pm 170$

Driftwood from terrace at Prinsesse Ingeborg Halvø $\left(81^{\circ} 35^{\prime} \mathrm{N}\right.$ Lat, $16^{\circ}$ $26^{\prime}$ W Long), Kronprins Christian Land, North Greenland. Found on a terrace $12 \mathrm{~m}$ above sealevel. The barren gravel terrace is an old raised beach; $25 \mathrm{~m}$ behind the driftwood a Paleo-Eskimo camp site with flint implements of Independence I Culture was situated. It is believed that the driftwood dates the time when the terrace was at sealevel and when the people of Independence I Culture inhabited the place (Knuth, 1954, 1956). Coll. 1952 and subm. 
by Eigil Knuth, National Museum, Copenhagen. (Age $2090 \pm 170$ в.c.) Comment: compare K-563 and K-564 (Copenhagen IV).

K-150. Jørgen Brønlund Fjord

$3290 \pm 130$

Driftwood from terrace at Jørgen Brønlund Fjord $\left(32^{\circ} 10^{\prime} \mathrm{N}\right.$ Lat, $31^{\circ}$

14' W Long), Pearyland, North Greenland. Found on a terrace, ("Deltaterrasserne"), $12.5 \mathrm{~m}$ above sealevel, considered to be an old raised beach. On the terrace a Paleo-Eskimo camp site without implements was situated. It is believed that the driftwood dates the time when the terrace was at sealevel (Knuth, 1954, 1956). Coll. 1950 and subm. by Eigil Knuth, National Museum, Copenhagen. (Age $1340 \pm 130$ в.c.)

\section{K-142. Kap Holbaek}

$3030 \pm 130$

Charcoal from Kap Holbaek ( $80^{\circ} 39^{\prime} \mathrm{N}$ Lat, $23^{\circ} 26^{\prime}$ W Long), Danmark Fjord, North Greenland. Sample originates from a fireplace of a Paleo-Eskimo settlement situated on a gravel terrace 5 to $6 \mathrm{~m}$ above sealevel and belonging to Independence II Culture. The charcoal originates from driftwood that presumably was collected by the Eskimos from the same terrace (Knuth, 1954, 1956). Coll. 1954 and subm. by Eigil Knuth, National Museum, Copenhagen. (Age $1080 \pm 130$ в.с.) Comment: compare K-565 (Copenhagen IV).

\section{Iceland}

\section{Hekla series}

Samples taken below tephra (clastic ejectamenta) layers from the volcano Hekla, Iceland. During the last 6000 to $7000 \mathrm{yr}$ Hekla has had five cycles of activity with an average length of ca. $1400 \mathrm{yr}$, each one starting with a rather basic eruption and ending with a violent and highly explosive acid eruption. The three oldest of the strongly acid tephra layers are designated $\mathrm{H}_{5}, \mathrm{H}_{4}$, and $\mathrm{H}_{3}$. Samples date the layers $\mathrm{H}_{5}, \mathrm{H}_{4}$, and, indirectly, $\mathrm{H}_{3}$ (Thorarinsson, 1954). Coll. and subm. by S. Thorarinsson, Museum of Natural History, Reykjavik.

K-141. Kraeklingahlid, $\mathbf{H}_{5}$

Average: $6610 \pm 170$

Peat, Kraeklingahlid (65 $44^{\prime} \mathrm{N}$ Lat, $18^{\circ} 12^{\prime} \mathrm{W}$ Long), Eyjafjördur, North Iceland. The peat lay immediately underneath the tephra layer $H_{5}$. (Average age $4660 \pm 170$ B.c.) Date is the average of two measurements:

$$
\begin{aligned}
& \text { K-141A. } \\
& \text { K-141B. }
\end{aligned}
$$

K-140. Kraeklingahlid, $\mathbf{H}_{4}$

$$
6520 \pm 190
$$$$
6710 \pm 250
$$

Average: $4030 \pm 120$

Peat, Kraeklingahlid $\left(65^{\circ} 41^{\prime}\right.$ N Lat, $18^{\circ} 08^{\prime} \mathrm{W}$ Long), Eyjafjördur, North Iceland. Sample lay immediately underneath the tephra layer $\mathrm{H}_{4}$. (Average age $2080 \pm 120$ в.c.) Date is the average of two measurements:

K-140A.

K-140B.

K-139. Laxargljufur

Charcoal, Laxargljufur $\left(65^{\circ} 49^{\prime} \mathrm{N}\right.$ Lat, $17^{\circ} 19^{\prime} \mathrm{W}$ Long), North Iceland. From charcoal layer immediately underneath the Younger Laxa lava flow $N$ of Laxargljufur. The charcoal layer was formed when the lava overflowed 
brushwood vegetation, and it is therefore of exactly the same age as the lava flow. Studies of soil sections near the Laxa canyon led to the conclusion that the Younger Laxa lava was about $700 \mathrm{yr}$ younger than the tephra layer $\mathrm{H}_{3}$. Supposed age of the Younger Laxa lava 1800 to 2300 B.P. (Thorarinsson, 1954). (Age $360 \pm 140$ B.C.) Comment: material from the same layer was dated by Yale (Y-87, $1940 \pm 270)$; compare also the dating of $\mathrm{H}_{3}$ (Y-85, $2720 \pm 130$ (Preston, Person, and Deevey, 1955).

\section{Italy}

\section{K-151. Barumini, Sardinia}

$3420 \pm 200$

Wood from Nuraghe, Barumini $\left(39^{\circ} 42^{\prime} \mathrm{N}\right.$ Lat, $9^{\circ} 01^{\prime} \mathrm{E}$ Long), Cagliari, Sardinia. From a beam in a wall of the ground-floor chamber in the central tower, which belongs to the simple type. The earliest simple nuraghi go back to the Middle Bronze Age or about the middle of the 2nd millenium B.c. (Lilliu, 1959). (Age $1470 \pm 200$ в.c.)

\section{E. Netherlands}

K-143. St. Walburgkerk

$1380 \pm 120$

Wood from St. Walburg Church at Groningen $\left(53^{\circ} 12^{\prime} \mathrm{N}\right.$ Lat, $6^{\circ} 36^{\prime} \mathrm{E}$ Long), Netherlands. Subm. by HI. de Vries. (Age A.D. $570 \pm 120$ ). Comment: wood of the same origin has been dated by several laboratories: de Vries and Barendsen (1954; not corrected for Suess effect); Nydal and Sigmond (1957) ; Münnich (1957), Olson and Broecker (1959); Shutler and Damon (1959); Olsson (1959).

\section{REFERENCES}

Date lists:

Copenhagen I. Anderson, Levi, and Tauber, 1953

Copenhagen II. Tauber, 1956

Copenhagen IV. Tauber, 1960

Anderson, E. C., Levi, Hilde, and Tauber, Henrik, 1953, Copenhagen natural radiocarbon measurements, I: Science, v. 1118, p. 6-9.

Barker, H., and Mackey, C. J., 1959, British Museum natural radiocarbon measurements I: Am. Jour. Sci. Radioc. Supp., v. 1, p. 81-86.

Fergusson, G. J., 1958, Reduction of atmospheric radiocarbon concentration by fossil carbon dioxide and the mean life of carbon dioxide in the atmosphere: Royal Soc. [London] Proc., v. 243A, p. 561.

Iversen, Johs., 1953, Radiocarbon dating of the Allerød Period: Science, v. 118, p. 9.11.

Knuth, Eigil, 1954, The Paleo-Eskimo Culture of Northeast Greenland elucidated by three new sites: Am. Antiquity, v. 19, p. 367-381.

1956, Archaeology of the farthest North: Internat. Cong. Americanists, 32nd,

Krog, Harald, 1954, Pollen analytical investigation of a C-14 dated Allerød section from Ruds Vedby: Danmarks geol. Unders $\varnothing$ gelse, reeks 2, no. 80, p. 120-139.

Larsen, Helge, 1950, Archaeological investigations in southwestern Alaska: Am. Antiquity, v. 15 , p. $177-186$.

, 1951, De dansk-amerikanske Alaska-ekspeditioner 1949-50: Geografisk tidskr., v. 5l, p. 63-93. [English summary, p. 92-93]. v. 6, no. 45 .

Larsen, Helge, and Meldgaard, J., 1958, Paleo-Eskimo Cultures in Disko Bugt, West Greenland: Meddelelser om Gronland, v. 161, no. 2, p. 1-75. 
Levi, Hilde, and Tauber, Henrik, 1955, Datierung der Pfahlbausiedlung Egolzwil-3 mit Hilfe der Kohlenstoff-14-Methode: Das Pfahlbauproblem, in Monographien zur Ur- und Frühgeschichte der Schweiz, v. 11, p. 113-115.

Lilliu, G., 1959, The nuraghi of Sardinia: Antiquity, v. 33, no. 129, p. 36.

Münnich, K. O., 1957, Heidelberg natural radiocarbon measurements I: Science, v. 126, p. 194-199.

Olson, E. A., and Broecker, W. S., 1959, Lamont natural radiocarbon measurements V: Am. Jour. Sci. Radioc. Supp., v. 1, p. 1-28

Olsson, Ingrid, 1959, Uppsala natural radiocarbon measurements I: Am Jour. Sci. Radioc. Supp. v 1, p, 87-102.

Östlund, H. G., 1957, Stockholm natural radiocarbon measurements I: Science, v. 126, p. 493-497.

Preston, R. S., Person, Elaine, and Deevey, E. S., 1955, Yale natural radiocarbon measurements II: Science, v. 122, p. 954-960.

Shutler, Dick, Jr., and Damon, P. E., 1959, University of Arizona radiocarbon dates II: Am. Jour. Sci. Radioc. SuPp., v. 1, 59-62.

Suess, H E., 1954, U. S. Geological Survey radiocarbon dates I: Science, v. 120, p. 467473.

1955, Radiocarbon concentration in modern wood: Science, v. 122, p. 415-417.

Tauber, Henrik, 1956, Copenhagen natural radiocarbon measurements II: Science, v. 124, p. $879-881$.

p. 12-25. 1960 , Copenhagen radiocarbon dates IV: Am. Jour. Sci. Radioc. Supp., v. 2,

Thorarinsson, Sigurdur, 1954, The tephra-fall from Hekla on March 20th, 1947: v. 2, no. 3 , in series "The Eruption of Hekla 1947-1948": Reykjavik, Societas Scientiarum Islandica, 68 p., 10 pls.

Troels-Smith, J., 1953, Erteb $\varnothing l l e$ Culture-Farmer Culture: Aarbøger for Nordisk Oldkyndighed og Historie, Copenhagen, p. 1-62. 879.

Willis, E. H., Tauber, Henrik, and Münnich, K. O., 1960, Variations in the atmospheric radiocarbon concentration over the past 1300 years: Am. Jour. Scr. Radioc. SupP.,

Vogt, E., 1951, Das steinzeitliche Uferdorf Egolzwil-3 (Kt. Luzern), Bericht über die Ausgrabung 1950: Zeitschr. schweiz. Arkaeol. u. Kunstgeschichte, v. 12, no. 4.

Vries, Hessel de, 1958, Variation in concentration of radiocarbon with time and location on Earth: Koninkl. Nederlandske Akad. Wetensch. Proc., ser. B, v. 61, no. 2, p. 1-9.

Vries, Hessel de and Barendsen, G. W., 1954, Measurements of age by the Carbon-14 technique: Nature, v. 174, p. 11138-1141.

Vries, Hessel de, Barendsen, G. W., and Waterbolk, H. T., 1958, Groningen radiocarbon dates II: Science, v. 127, p. 129-137. 